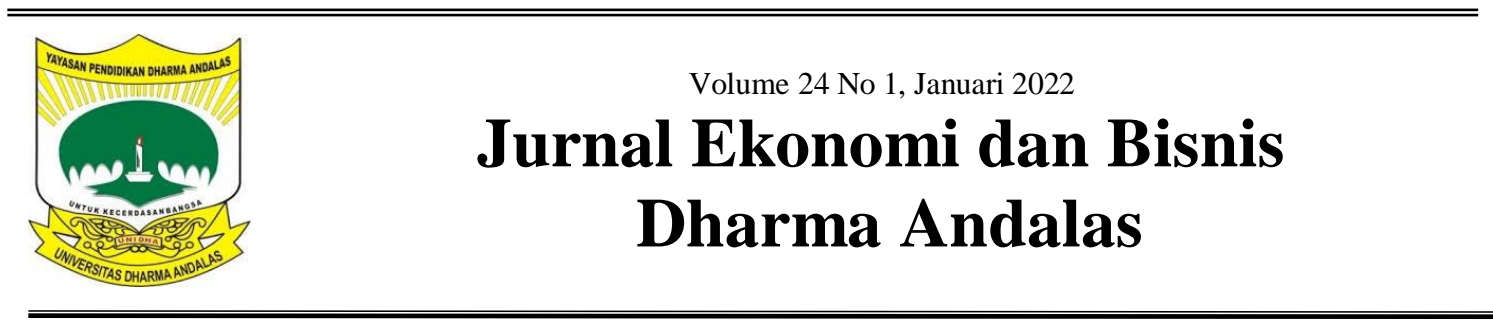

\title{
Analisis Sikap Dosen Terhadap Pembelajaran Online Pada Masa Pandemi Covid-19
}

\author{
Mellyna Eka Yan Fitri ${ }^{1}$, Lasti Yossi Hastini' ${ }^{2}$, Lucy Chairoel ${ }^{3}$ \\ Fakultas Ekonomi dan Bisnis Universitas Dharma Andalas ${ }^{1,2,3}$ \\ email:eka.melly@gmail.com \\ lastiyossi@gmail.com \\ lucy.chairoel69@gmail.com
}

\begin{abstract}
This study aims to provide an overview of the difficulties experienced by lecturers and find out the benefits felt by lecturers when carrying out online learning. Based on The Theory of Planned Behavior and Technology Acceptance Model, this research was conducted qualitatively on lecturers of S1 Management at Dharma Andalas University. There was 18 sample of Lecturers of Management Program in Dharma Andalas University. The results showed that the general problem felt was the availability of infrastructure, and the lack of creativity of the lecturers in the learning process, some lecturers did not feel the benefits of online learning.
\end{abstract}

Keywords: attitude, e-learning,TPB, TAM

\begin{abstract}
ABSTRAK
Penelitian ini bertujuan untuk memberikan gambaran mengetahui kesulitan yang dialami dosen dan mengetahui manfaat yag dirasakan oleh dosen ketika melaksanakan pembelajaran daring. Dengan didasarkan pada The Theory of Planned Behavior dan Technology Acceptance Model, penelitian ini dilakukan secara kualitatif pada dosen S1 Manajemen Universitas Dharma Andalas. Terdapat 18 partisipan dari dosen S1 Manahemen dan hasilnya menunjukkan bahwa permasalahan umum yang dirasakan adalah ketersediaan prasarana, dan kurangnya kreativitas dosen dalam proses pembelajaran, sebagian dosen tidak merasakan manfaat dari pembelajaran online.
\end{abstract}

Kata Kunci: attitude, e-learning, TPB, TAM

\section{PENDAHULUAN}

Saat ini dunia tengah mengalami era disruption. Salah satu sumber munculnya disrupsi ini adalah Revolusi Industri 4.0. Perubahan dunia industri dengan adanya Revolusi Industri 4.0 menyebabkan terjadinya perubahan pada cara bekerja seperti ada bagian pekerjaan yang biasanya dilakukan oleh manusia digantikan oleh mesin (Stock et al., 2018). Banyak lapangan pekerjaan hilang disisi lain bermunculan jenis pekerjaan baru (Dirjen Dikti Kemendikbud, 2020).

Di tengah kesibukan masyarakat dunia menghadapi disrupsi akibat revolusi industri 4.0, dunia dipaksa menghadapi disrupsi lain yaitu pandemik Covid-19. Kondisi ini memaksa perubahan kehidupan lebih cepat dari pada yang diperkirakan. Semenjak Maret 2020 pendidikan di Indonesia secara 
umum berubah dari pembelajaran tatap muka di kelas menjadi pembelajaran secara online atau sering juga disebut pembelajaran daring (dalam jaringan). Mulai dari Pendidikan Anak Usia Dini hingga Perguruan Tinggi melaksanakan pembelajaran daring ini akibat menyebarnya virus Covid-19 ini. Setiap guru dan dosen juga para peserta didik dipaksa untuk berubah dan menyesuaikan diri dengan pembelajaran daring ini.

Bagi negara-negara maju pelaksanaan pembelajaran daring atau jarak jauh atau sering juga disebut pembelajaran alternatif akibat adanya pandemik Covid-19 bukan menjadi hal yang berat, karena mereka sudah memiliki infrastruktur, sumber daya manusia yang memiliki kompetensi, serta teknologi yang memadai. Sebaliknya negara-negara berkembang cenderung mengalami kesulitan, entah itu karena ketersediaan infrastruktur dan teknologi yang masih terbatas atau karena kurangnya kompetensi yang dimiliki oleh sumber daya manusianya (Abubakar Yunusa et al., 2020). Kesulitan yang sama dirasakan oleh Perguruan Tinggi di Indonesia. Baik dosen maupun mahasiswa mengeluhkan kondisi yang mengharuskan mereka untuk menjalani pembelajaran daring atau jarak jauh ini.

Di Nigeria ditemukan bahwa dosen di sana cukup yakin bahwa mereka mampu melakukan perubahan dari cara pembelajaaran tradisional (tatap muka langsung) menjadi pembelajaran secara online, namun mereka mengeluhkan infrastruktur yang kurang memadai untuk mendukung pelaksanaan pembelajaran jarak jauh ini (Abubakar Yunusa et al., 2020). Pada salah satu kampus perhotelan swasta di Manila untuk menunjang pembelajaran jarak jauh ini menggunakan aplikasi
e-Learning Access Program (eLeAP). Meskipun merasa terbantu dengan penggunaan aplikasi ini pada kenyataannya mahasiswa lebih menyukai pembelajaran tatap muka untuk memenuhi keterampilan teknis dibidang perhotelan (Andalecio et al., 2020).

Di Indonesia beberapa penelitian juga telah menyorot penggunaan pembelajran online ini. Di Universitas PGRI Yogyakarta mahasiswanya menyatakan pembelajaran online yang digunakan selama pandemic covid-19 ini melalui e-mail. Pemanfaatan email tentunya berbeda dengan pemanfaatan zoom ataupun google meet dimana interaksi mahasiswa dengan dosen bisa langsung dilakukan seperti pembelajaran tatap muka. Ini memperlihatkan bahwa kemampuan penggunaan teknologi masih sangat kurang. Selain itu pembelajaran yang diberikan secara daring tidak dapat diserap sempurna oleh mahasiswa (Dewantara \& Nurgiansah, 2020). Sementara pada Program Studi Pendidikan Biologi di FKIP Universitas Jambi mahasiswa mengeluhkan bahwa mereka harus mengeluarkan biaya ekstra untuk pembelajaran online ini, Mahasiswa mengalami kesulitan memahami materi yang diberikan secara daring (Sadikin et al., 2020).

Di Universitas Dharma Andalas khususnya pada dosen S1 Manajemen telah dilakukan penelitian pendahuluan terkait pilihan pembelajaran yang ingin diterapkan. Dari 27 orang jumlah Dosen S1 Manajemen Universitas Dharma Andalas yang memungkinkan untuk dilibatkan pada penelitian awal, terjaring 21 orang yang bersedia ikut serta dalam menjawab pertanyaan yang diberikan peneliti. Dari 21 orang tersebut $85,7 \%$ memilih pembelajaran secara luar jaringan atau tatap muka langsung. 


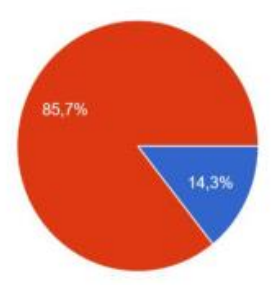

Dalam jaringan (daring) Tatap muka / luar jaringan (luring)

\section{Gambar 1}

\section{Pilihan Metode Pembelajaran}

Ini menjadi hal yang menarik untuk diteliti lebih lanjut mengapa dosen-dosen ini tidak menyukai pembelajaran daring. Padahal di negaranegara lain yang juga mengalami disrupsi akibat Revolusi Industri 4.0 ditambah dengan adanya pandemik Covid-19 sama-sama memilih penggunaan daring ini untuk pelaksanaan pembelajaran di sekolah maupun kampus-kampusnya.

Dengan mempertimbangkan kondisi tersebut di atas maka penelitian ini akan membahas tentang "Analisis Sikap Dosen tentang Pembelajaran Online pada Masa Pandemik Covid-19”.

Penelitian akan dilakukan secara kualitatif dan dibatasi pada dosen S1 Manajemen saja mengingat Program Studi ini memiliki jumlah dosen dan mahasiswa yang paling banyak di Universitas Dharma Andalas, sehingga permasalahan pembelajaran online menjadi lebih kompleks dialami oleh dosen dan mahasiswanya.

Permasalahan yang diteliti adalah selama pembelajaran online. Sikap dilihat dari bagaimana kesulitan yang dialami oleh dosen, dan manfaat yang dirasakan oleh dosen saat melaksanakan pembelajaran online di masa Pandemi Covid-19. Tujuan penelitian ini adalah selama pembelajaran daring, untuk mengetahui kesulitan yang dialami dan untuk mengetahui manfaat yang dirasakan oleh dosen.

Dengan mengetahui gambaran kesulitan dan manfaat yang dirasakan oleh dosen ini diharapkan Universitas Dharma Andalas dapat menyusun kebijakan untuk mempermudah dosen dalam melaksanakan pembelajaran terutama karena kondisi Pandemik Covid-19 belum dapat dipastikan akan berlangsung sampai kapan.

\section{The Theory of Planned Behavior}

Pembahasan sikap pada penelitian ini didasarkan pada The Theory of Planned Behavior. Teori ini berusaha menjelaskan bagaimana memprediksi apakah individu akan melakukan atau tidak melakukan suatu perilaku. Sikap terhadap perilaku biasanya ditentukan oleh behavioral beliefs atau keyakinan atas konsekuensi apa yang akan diperoleh bila melakukan perilaku tertentu. Keyakinan atau belief ini merupakan penilaian-penilaian individu secara subjektif terhadap dunia sekitarnya, serta pemahaman tentang diri dan lingkungannya. Behavioral belief diperoleh dengan mengetahui keyakinan individu terhadap dampak berupa manfaat dan kerugian apabila ia melakukan atau tidak melakukan perilaku tertentu. Keyakinan ini dapat memperkuat sikap individu terhadap perilaku tersebut (Ajzen, 1991).

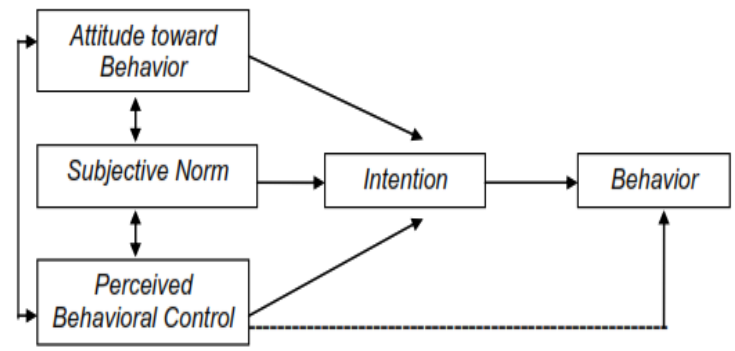

Gambar 2

The Theory of Planned Behavior (Ajzen, 1991)

\section{Technology Acceptance Model (TAM)}

The theory of planned behavior telah banyak dimodifikasi pada teoriteori lainnya. Salah satu modifikasi dari The Theory of Planned Behavior adalah Technnology Acceptance Model (TAM) yang mencoba memprediksi penerimaan penggunaan teknologi baru. Technology 
Acceptance Model menggunakan prinsip yang sama dengan The Theory of Planned Behavior (Mahyarni, 2013).

Technology Acceptance Model menempatkan faktor sikap dari tiap individu dalam pengguna teknologi dengan dua variabel yaitu kemudahan dalam penggunaan (ease of use) dan kemanfaatan (usefulness).

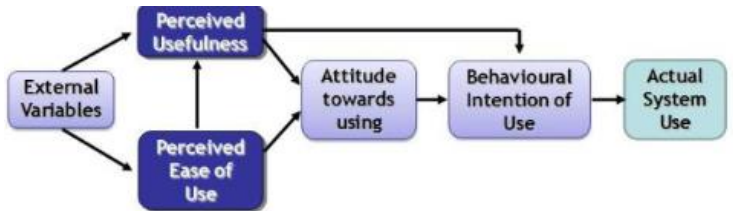

Gambar 3

Model Technology Acceptance Model (TAM) (Chairoel et al., 2020)

\section{Pembelajaran Online}

Pembelajaran jarak jauh adalah pembelajaran yang antara instruktur dan peserta yang berada pada lokasi yang berbeda. Online learning merupakan bagian dari pembelajaran jarak jauh yang menggunakan teknologi internet dalam proses pembelajarannya. Instruktur dan peserta pembelajaran tidak harus mengakses bahan pembelajaran pada waktu bersamaan (Siemens et al., 2015). E-learning adalah bentuk pembelajaran yang didukung elektronik secara prosedural yang bertujuan untuk mempengaruhi konstruksi pengetahuan, yang diterapkan berdasarkan pengetahuan dasar yang sudah dimiliki peserta ditambah dengan pengalaman beserta praktek di lapangan. Dalam hal ini peserta dan instruktur dapat berinteraksi dan berkomunikasi secara langsung atau melalui jaringan dengan memanfaatkan teknologi (Tavangarian et al., 2004). Dalam hal ini online learning juga merupakan bagian dari e learning.

Di antara pembelajaran tatap muka dengan online learning dikenal istilah blended learning, sering juga disebut hybrid learning. Blended learning adalah upaya untuk mendesain ulang proses pembelajaran agar lebih berkembang, dilakukan secara terjadwal, di mana interaksi antara instruktur dan peserta dapat terjadi secara langsung dan visual (Medina, 2018). Blended learning ini merupakan penggabungan antara metode pembelajaran sinkron dan asinkron (Hastini et al., 2020).

\section{METODOLOGI PENELITIAN}

Penentuan filosofi penelitian didasarkan pada tiga unsur yaitu ontology, epistemology dan aksiologi. penelitian ini menggunakan filosofi Interpretivis karena secara ontology bersifat kompleks mengandung berbagai makna, interpretasi dan realitas. Sumber data penelitian terdiri atas data primer dan data sekunder. Penelitian ini merupakan penelitian kualitatif, maka untuk melaksanakannya dibutuhkan data primer yang diperoleh dari tangan pertama yaitu dengan menggunakan deep interview. Objek pada penelitian ini adalah dosen S1 Manajemen Universitas Dharma Andalas. Saat ini jumlah dosennya sebanyak 32 orang. Dari jumlah tersebut dikurangi dengan 1 orang dosen yang sedang tugas belajar, 1 orang baru purna bakti serta 3 orang sebagai peneliti pada penelitian ini sehingga jumlah objek penelitian yang dapat berkontribusi dalam penelitian ini adalah 27 orang. Dari 27 orang tersebut juga akan dikurangi dengan pejabat structural dan dosen-dosen yang baru mulai mengajar kembali setelah selesai menjalani tugas belajar. Jumlahnya menjadi sekitar 18 orang.

Di dalam penelitian kualitatif tidak digunakan istilah sampel seperti pada penelitian kuantitatif. Istilah yang lebih tepat digunakan adalah partisipan. Dari 18 orang jumlah dosen S1 Manajemen Universitas Dharma Andalas yang dapat berkontribusi dalam penelitian ini, maka beberapa di antaranya akan menjadi partisipan. Jumlah partisipan yang diikutsertakan 
sedikitnya 5 orang, tergantung dari keseragaman jawaban yang akan ditemukan saat pengumpulan data. Variabel penelitian ini mengikuti The Theory of Planned Behavior dan Technologi Acceptance Model.

\section{Analisis Karakteristik Partisipan}

Dalam penenelitian ini partisipan dibagi menjadi 2 yaitu partisipan kunci dan partisipan utama. Partisipan kunci adalah partisipan yang sudah melaksanakan membelajaran online sebelum adanya pandemic Covid-19. Mereka melaksanakan pembelajaran online karena berhasil mendapatkan hibah SPADA Indonesia (Sistem Pembelajaran Daring Indonesia) dari Kemenristek Dikti. Pelaksanaan pembelajaran online melalui hibah SPADA Indonesia ini dilakukan langsung di bawah pengawasan Kemenristek Dikti. Selain itu salah satu partisipan kunci juga mengikuti pelatihan dosen penggerak MBKM yang dilaksanakan oleh Kemenristek Dikti sehingga ia memiliki pemahaman yang komprehensif tentang pelaksanaan MBKM ini. Partisipan kunci pada penelitian ini terdiri atas 2 orang dosen S1 Manajemen. Keduanya berusia antara 30 sampai kurang dari 50 tahun. Dan 8 orang sebagai partisipan utama yang terlibat dalam penelitian ini. Jumlah 8 orang ditetapkan setelah diperoleh kemiripan di dalam jawaban yang mereka berikan pada saat deep interview. Berikut ini kompilasi karakteristik partisipan pada penelitian ini:

Tabel 2

\section{Karakteristik Partisipan}

\begin{tabular}{|c|c|c|c|c|c|c|}
\hline \multirow[t]{2}{*}{ Partisipan } & \multicolumn{2}{|c|}{$\begin{array}{l}\text { Kelompok } \\
\text { Umur } \\
\text { (tahun) }\end{array}$} & \multicolumn{2}{|c|}{$\begin{array}{l}\text { Jenis } \\
\text { Kelamin }\end{array}$} & $\begin{array}{l}\text { Matakuliah } \\
\text { Diampu }\end{array}$ & yang \\
\hline & $\begin{array}{l}30 \\
\text { sampai } \\
<50\end{array}$ & $\begin{array}{l}\geq \\
50\end{array}$ & $\begin{array}{l}\text { Laki- } \\
\text { laki }\end{array}$ & $\begin{array}{l}\text { Perem- } \\
\text { puan }\end{array}$ & Teoritis Hitungan & $\begin{array}{l}\text { Teoritis } \\
\& \\
\text { Hitungan }\end{array}$ \\
\hline \multicolumn{7}{|l|}{ Kunci } \\
\hline 1 & $\mathrm{v}$ & & & $\mathrm{V}$ & & $\mathrm{v}$ \\
\hline 2 & $\mathrm{v}$ & & $\mathrm{v}$ & & & $\mathrm{v}$ \\
\hline
\end{tabular}

\begin{tabular}{|c|c|c|c|c|c|c|}
\hline \multicolumn{7}{|c|}{ Utama } \\
\hline A & & $\mathrm{v}$ & & $\mathrm{v}$ & & $\mathrm{v}$ \\
\hline B & & $\mathrm{v}$ & & $\mathrm{v}$ & & $\mathrm{v}$ \\
\hline C & & & $\mathrm{v}$ & & & $\mathrm{v}$ \\
\hline D & & $\mathrm{v}$ & & $\mathrm{v}$ & $\mathrm{v}$ & \\
\hline E & $\mathrm{v}$ & & $\mathrm{v}$ & & $\mathrm{v}$ & \\
\hline $\mathrm{F}$ & $\mathrm{v}$ & & $\mathrm{v}$ & & & $\mathrm{v}$ \\
\hline G & $\mathrm{v}$ & & & $\mathrm{v}$ & $\mathrm{v}$ & \\
\hline $\mathrm{H}$ & $\mathrm{x}$ & & $\mathrm{v}$ & & & $\mathrm{v}$ \\
\hline
\end{tabular}

Sumber: Hasil Analisis 2021

Analisis Sikap terhadap Perilaku

Analisis ini didasarkan pada dua pertanyaan penelitian yaitu:

1. RQ1: Apakah kesulitan yang dialami oleh dosen ketika melaksanakan pembelajaran daring?

2. RQ2: Apakah manfaat yang dirasakan oleh dosen ketika melaksanakan pembelajaran daring?

RQ1 merupakan pertanyaan yang ingin mengetahui sekaligus mengkonfirmasi kesulitan-kesulitan yang dialami dosen pada saat pelaksanaan pembelajaran secara daring. Pembelajaran dengan daring ini telah dilaksanakan secara terpaksa akibat adanya pandemic Covid-19. Tepatnya pelaksanaan pembelajaran daring ini mulai dilakukan pada pertengahan Maret 2020 semester genap tahun ajaran 2019/2020. Sampai saat ini pada November 2021 pelaksanaan daring tetap dilaksanakan terutama pada kelaskelas besar. S1 Manajemen memiliki kategori kelas besar di setiap mata kuliah yang dimilikinya.

Berbeda dengan RQ1, yang melihat kesulitan maka RQ2 justru ingin melihat manfaat yang dirasakan dengan adanya pembelajaran online ini. Seperti dua sisi mata uang, di samping kesulitan yang kurang disukai oleh setiap manusia selalu ada manfaat yang bisa diambil pada suatu peristiwa atau tindakan. 


\section{Kesulitan dalam Pelaksanaan Pembelajaran Online \\ Kesulitan yang paling banyak} dirasakan oleh partisipan adalah berkaitan dengan ketersediaan prasarana (PS), terutama yang berhubungan dengan jaringan atau koneksi internet. Ketidakleluasaan dalam interaksi sosial terutama dalam hal pengawasan terhadap keseriusan peserta didik juga dirasakan oleh partisipan meskipun hanya 37,5\% yang menyatakannya. Selain itu kesulitan-kesulitan lain juga dirasakan oleh beberapa partisipan secara berbedabeda.

Tabel 3

\section{Frekuensi Jawaban dari Partisipan} untuk RQ1

\begin{tabular}{lccccc}
\hline Kode tahap 1 & Jumlah & $\%$ & Kode tahap 2 & Jumlah & $\%$ \\
\hline Prasarana (Ps) & 6 & 75 & $\begin{array}{l}\text { Prasarana } \\
(\text { Ps) }\end{array}$ & 6 & 75 \\
\hline $\begin{array}{l}\text { Metode } \\
\text { pembelajaran } \\
\text { (MP) }\end{array}$ & 2 & 25 & & & \\
$\begin{array}{l}\text { Interaksi } \\
\text { Sosial (IS) }\end{array}$ & 3 & 37,5 & $\begin{array}{l}\text { Kreativitas } \\
\text { dalam } \\
\text { proses } \\
\text { pembelajar } \\
\text { an (KPP) }\end{array}$ & 4 & 50 \\
$\begin{array}{l}\text { Motivasi } \\
\text { mahasiswa } \\
\text { (MM) }\end{array}$ & 1 & 12,5 & & \\
$\begin{array}{l}\text { Beban kerja } \\
\text { naik (BK+) }\end{array}$ & 2 & 25 & & \\
\hline
\end{tabular}

Sumber : Hasil Analisis, 2021

Bila diperhatikan kesulitan metode pembelajaran (MP), interaksi sosial (IS), motivasi mahasiswa (MM) dan beban kerja naik $(\mathrm{BK}+)$, semua itu merupakan bagian dari kreativitas dosen dalam meramu proses pembelajaran daring, oleh sebab itu dilakukan lagi pengkodean tahap 2 yang menggabungkan keempat kesulitan tersebut. Dari hasil pengkodean kedua baik kesulitan karena prasarana maupun karena kreativitas dosen dalam proses pembelajaran memiliki nilai yang samasama tinggi (tabel 3). Berikut tabel 4 adalah pengkodean jawaban partisipan pada RQ1.
Tabel 4

Pengkodean Jawaban Partisipan pada

RQ1

\begin{tabular}{|c|c|c|c|}
\hline Partisipan & Kata Kunci & $\begin{array}{l}\text { Pengkodean } \\
\text { Tahap } 1\end{array}$ & $\begin{array}{l}\text { Pengkodean } \\
\text { Tahap } 2\end{array}$ \\
\hline \multirow[t]{4}{*}{ A } & $\begin{array}{l}\text { Jaringan atau sinyal } \\
\text { terutama pada } \\
\text { mahasiswa di luar } \\
\text { daerah }\end{array}$ & $\begin{array}{l}\text { Prasarana } \\
\quad(P s)\end{array}$ & $\begin{array}{l}\text { Prasarana } \\
\quad(P s)\end{array}$ \\
\hline & $\begin{array}{l}\text { Mahasiswa cenderung } \\
\text { malas dan tidak mau } \\
\text { mencari dari sumber } \\
\text { pembelajaran lain }\end{array}$ & $\begin{array}{l}\text { Motivasi } \\
\text { mahasiswa } \\
\text { (MM) }\end{array}$ & \multirow{3}{*}{$\begin{array}{c}\text { Kreativitas } \\
\text { dalam proses } \\
\text { pembelajaran } \\
\text { (KPP) }\end{array}$} \\
\hline & $\begin{array}{l}\text { Sulit dalam } \\
\text { menjelaskan proses }\end{array}$ & $\begin{array}{c}\text { Metode } \\
\text { pembelajaran } \\
\text { (MP) }\end{array}$ & \\
\hline & $\begin{array}{l}\text { Pengawasan keseriusan } \\
\text { mahasiswa }\end{array}$ & $\begin{array}{l}\text { Interaksi } \\
\text { Sosial (IS) }\end{array}$ & \\
\hline \multirow[t]{2}{*}{ B } & $\begin{array}{l}\text { Sulit menjelaskan } \\
\text { matakuliah hitungan } \\
\text { terutama yang } \\
\text { membutuhkan proses }\end{array}$ & $\begin{array}{c}\text { Metode } \\
\text { pembelajaran } \\
\text { (MP) }\end{array}$ & \multirow{2}{*}{$\begin{array}{c}\text { Kreativitas } \\
\text { dalam proses } \\
\text { pembelajaran } \\
\text { (KPP) }\end{array}$} \\
\hline & $\begin{array}{l}\text { Beban kerja dosen jadi } \\
\text { bertambah banyak } \\
\text { terutama urusan } \\
\text { administratif dengan } \\
\text { system yang berubah- } \\
\text { ubah }\end{array}$ & $\begin{array}{c}\text { Beban kerja } \\
\text { naik (BK+) }\end{array}$ & \\
\hline \multirow[t]{3}{*}{ C } & $\begin{array}{l}\text { Jaringan atau sinyal } \\
\text { peserta kuliah }\end{array}$ & \multirow{3}{*}{$\begin{array}{l}\text { Prasarana } \\
\quad \text { (Ps) }\end{array}$} & \multirow{3}{*}{$\begin{array}{l}\text { Prasarana } \\
\quad \text { (Ps) }\end{array}$} \\
\hline & $\begin{array}{l}\text { Kuota internet peserta } \\
\text { kuliah }\end{array}$ & & \\
\hline & $\begin{array}{l}\text { Kondisi listrik yang } \\
\text { kadang-kadang mati }\end{array}$ & & \\
\hline \multirow[t]{2}{*}{ D } & $\begin{array}{l}\text { Jaringan atau sinyal } \\
\text { peserta kuliah }\end{array}$ & $\begin{array}{l}\text { Prasarana } \\
\quad \text { (Ps) }\end{array}$ & $\begin{array}{l}\text { Prasarana } \\
\quad(P s)\end{array}$ \\
\hline & $\begin{array}{l}\text { Sulit mengawasi } \\
\text { keseriusan mahasiswa } \\
\text { saat kuliah }\end{array}$ & $\begin{array}{l}\text { Interaksi } \\
\text { Sosial (IS) }\end{array}$ & $\begin{array}{c}\text { Kreativitas } \\
\text { dalam proses } \\
\text { pembelajaran } \\
\text { (KPP) }\end{array}$ \\
\hline \multirow[t]{2}{*}{ E } & $\begin{array}{l}\text { Jaringan atau sinyal } \\
\text { peserta kuliah }\end{array}$ & \multirow{2}{*}{$\begin{array}{l}\text { Prasarana } \\
\quad(P s)\end{array}$} & \multirow{2}{*}{$\begin{array}{l}\text { Prasarana } \\
\quad(P s)\end{array}$} \\
\hline & $\begin{array}{l}\text { Ketersediaan kuota } \\
\text { internet bagi beberapa } \\
\text { orang peserta kuliah }\end{array}$ & & \\
\hline $\mathrm{F}$ & $\begin{array}{l}\text { Jaringan atau sinyal } \\
\text { peserta kuliah }\end{array}$ & $\begin{array}{l}\text { Prasarana } \\
\quad \text { (Ps) }\end{array}$ & $\begin{array}{l}\text { Prasarana } \\
\quad \text { (Ps) }\end{array}$ \\
\hline \multirow[t]{2}{*}{ G } & $\begin{array}{l}\text { Interaksi dengan } \\
\text { mahasiswa terbatas, } \\
\text { sehingga sulit } \\
\text { mengawasi keseriusan } \\
\text { mahasiswa }\end{array}$ & $\begin{array}{l}\text { Interaksi } \\
\text { Sosial (IS) }\end{array}$ & \multirow[t]{2}{*}{$\begin{array}{c}\text { Kreativitas } \\
\text { dalam proses } \\
\text { pembelajaran } \\
\text { (KPP) }\end{array}$} \\
\hline & $\begin{array}{l}\text { Memakan waktu lebih } \\
\text { banyak }\end{array}$ & $\begin{array}{l}\text { Beban kerja } \\
\text { naik (BK+) }\end{array}$ & \\
\hline H & $\begin{array}{l}\text { Jaringan atau sinyal } \\
\text { peserta kuliah }\end{array}$ & $\begin{array}{l}\text { Prasarana } \\
\text { (Ps) }\end{array}$ & $\begin{array}{l}\text { Prasarana } \\
\quad \text { (Ps) }\end{array}$ \\
\hline
\end{tabular}

Sumber: Hasil Analisis, 2021 


\section{Manfaat dalam Pelaksanaan Pembelajaran Online}

Terdapat 5 orang partisipan yang merasakan manfaat dari pembelajaran daring. Manfaat yang dirasakan terutama terkait dengan kreativitas dosen. Ini sejalan dengan pendapat partisipan kunci. Hal ini dapat dilihat pada tabel 5 berikut :

\section{Tabel 5}

Frekuensi Jawaban dari Partisipan untuk RQ2

\begin{tabular}{|c|c|c|c|c|c|}
\hline Kode tahap 1 & Jumlah & $\%$ & Kode tahap 2 & Jumlah & $\%$ \\
\hline $\begin{array}{l}\text { Kurang } \\
\text { merasa } \\
\text { manfaat } \\
(\mathrm{KM})\end{array}$ & 3 & 37,5 & $\begin{array}{l}\text { Kurang } \\
\text { merasa } \\
\text { manfaat } \\
(\mathrm{KM})\end{array}$ & 3 & 37,5 \\
\hline $\begin{array}{l}\text { Student } \\
\text { Center } \\
\text { Learning (SCL) }\end{array}$ & 3 & 37,5 & $\begin{array}{l}\text { Merasakan } \\
\text { manfaat } \\
\text { (MM) }\end{array}$ & 5 & 62,5 \\
\hline
\end{tabular}

Dosen (KD)

$\begin{array}{lll}\text { Fleksibilitas } & 3 & 37,5 \\ \text { (FI) }\end{array}$

Sumber : Hasil Analisis 2021

Hasil tabel 5 di atas diperoleh bahwa manfaat yang dirasakan oleh dosen adalah paling tinggi yaitu sekitar 50 persen. Selanjutnya bila diperhatikan bahwa student center learning, Kreativitas dosen dan fleksibilitas dapat dikelompokkan pada kondisi yang dirasakan manfaat oleh dosen. Jadi dari hal ini dilakukan pengkodean tahap 2 yang ternyata 62,5 persent merasakan manfaat dari pembelajaraan online tersebut. Berikut tabel 6 adalah pengkodean jawaban partisipasipan $\mathrm{RQ}$ 2.

Tabel 6

Pengkodean Jawaban Partisipan pada RQ2

\begin{tabular}{|c|c|c|c|}
\hline Partisipan & Kata Kunci & Pengkodean tahap 1 & Pengkodean tahap 2 \\
\hline \multirow[t]{2}{*}{ A } & Bagi mahasiswa efisiensi & \multirow{2}{*}{$\begin{array}{l}\text { Kurang merasa manfaat } \\
\qquad(\mathrm{KM})\end{array}$} & \multirow{2}{*}{$\begin{array}{l}\text { Kurang merasa manfaat } \\
\qquad(\mathrm{KM})\end{array}$} \\
\hline & Tidak ada manfaat bagi dosen & & \\
\hline B & Tidak ada manfaat & $\begin{array}{c}\text { Kurang merasa manfaat } \\
\qquad(\mathrm{KM})\end{array}$ & $\begin{array}{l}\text { Kurang merasa manfaat } \\
\qquad(\mathrm{KM})\end{array}$ \\
\hline $\mathrm{C}$ & Tidak ada manfaat & $\begin{array}{l}\text { Kurang merasa manfaat } \\
\qquad(\mathrm{KM})\end{array}$ & $\begin{array}{l}\text { Kurang merasa manfaat } \\
\qquad(\mathrm{KM})\end{array}$ \\
\hline $\mathrm{D}$ & Membuat mahasiswa lebih kreatif & Student Center Learning (SCL) & Merasakan manfaat (MM) \\
\hline \multirow[t]{2}{*}{$\mathrm{E}$} & Fleksibilitas waktu & Fleksibilitas (Fl) & \multirow{2}{*}{ Merasakan manfaat (MM) } \\
\hline & Kreativitas dalam pemberian materi & Kreativitas Dosen $(\mathrm{KD})$ & \\
\hline \multirow[t]{2}{*}{$\mathrm{F}$} & $\begin{array}{l}\text { Data atau materi update dan dapat } \\
\text { tersimpan dengan baik }\end{array}$ & Kreativitas Dosen (KD) & \multirow{2}{*}{ Merasakan manfaat (MM) } \\
\hline & Data atau materi mudah diakses & Student Center Learning (SCL) & \\
\hline \multirow[t]{3}{*}{ G } & $\begin{array}{c}\text { Mahasiswa lebih mudah mencari } \\
\text { artikel }\end{array}$ & Student Center Learning (SCL) & \multirow{3}{*}{ Merasakan manfaat (MM) } \\
\hline & $\begin{array}{l}\text { Bagi dosen waktunya lebih fleksibel } \\
\text { dan }\end{array}$ & Fleksibilitas (Fl) & \\
\hline & $\begin{array}{l}\text { Mudah mengupdate materi sesuai } \\
\text { kondisi viral saat ini }\end{array}$ & Kreativitas Dosen (KD) & \\
\hline \multirow[t]{3}{*}{$\mathrm{H}$} & Efisiensi waktu & Fleksibilitas (Fl) & \multirow{3}{*}{ Merasakan manfaat (MM) } \\
\hline & Mudah mengeksplore materi & Kreativitas Dosen (KD & \\
\hline & $\begin{array}{l}\text { Memungkinkan improvisasi } \\
\text { menggunakan teknologi }\end{array}$ & & \\
\hline
\end{tabular}

Sumber: Hasil Analisis, 2021 


\section{Kompilasi Jawaban Responden}

Kesiapan dosen dalam proses pembelajaran di era new normal ini menggunakan kombinasi The Theory of Planned Behavior dan Technology Acceptance Model. Dalam penelitian ini akan digali salah satunya adalah attitude toward behaviour. Sikap terhadap perilaku ditentukan oleh keyakinan atas konsekuensi apa yang diperoleh bila melakukan atau tidak melakukan perilaku tertentu (Ajzen, 1991). Technology Acceptance Model mengukur sikap dari persepsi tentang kemudahan penggunaan teknologi dan persepsi tentang manfaat penggunaan teknologi. Penelitian ini menggunakan jawaban dari RQ1 dan RQ2 untuk mengetahui sikap terhadap perilaku pembelajaran online. Di sini penggunaan teknologi diwakilkan dengan pembelajaran online karena kebanyakan dosen baru menyadari bahwa mereka perlu memanfaatkan teknologi dalam pembelajaran ketika mereka terpaksa melaksanakan pembelajaran online akibat adanya pandemic Covid-19.

\section{Tabel 8}

\section{Kompilasi Jawaban RQ1 dan RQ2}

\begin{tabular}{|c|c|c|}
\hline \multirow{2}{*}{ Partisipan } & RQ1 & $\mathrm{RQ2}$ \\
\hline & Kesulitan & Manfaat \\
\hline \multicolumn{3}{|c|}{ Prasarana (Ps) } \\
\hline A & $\begin{array}{l}\text { \& Kreativitas dalam } \\
\text { Proses Pembelajaran } \\
\text { (KPP) }\end{array}$ & $\begin{array}{l}\text { Kurang merasa } \\
\text { manfaat (KM) }\end{array}$ \\
\hline B & $\begin{array}{l}\text { Kreativitas dalam } \\
\text { Proses Pembelajaran } \\
\text { (KPP) }\end{array}$ & $\begin{array}{l}\text { Kurang merasa } \\
\text { manfaat (KM) }\end{array}$ \\
\hline C & Prasarana (Ps) & $\begin{array}{l}\text { Kurang merasa } \\
\text { manfaat (KM) }\end{array}$ \\
\hline \multicolumn{3}{|c|}{ Prasarana (Ps) } \\
\hline D & $\begin{array}{l}\text { \& Kreativitas dalam } \\
\text { Proses Pembelajaran } \\
\text { (KPP) }\end{array}$ & $\begin{array}{l}\text { Merasakan } \\
\text { Manfaat (MM) }\end{array}$ \\
\hline $\mathrm{E}$ & Prasarana (Ps) & $\begin{array}{l}\text { Merasakan } \\
\text { Manfaat (MM) }\end{array}$ \\
\hline $\mathrm{F}$ & Prasarana (Ps) & $\begin{array}{l}\text { Merasakan } \\
\text { Manfaat (MM) }\end{array}$ \\
\hline G & $\begin{array}{l}\text { Kreativitas dalam } \\
\text { Proses Pembelajaran } \\
\text { (KPP) }\end{array}$ & $\begin{array}{l}\text { Merasakan } \\
\text { Manfaat (MM) }\end{array}$ \\
\hline $\mathrm{H}$ & Prasarana (Ps) & $\begin{array}{l}\text { Merasakan } \\
\text { Manfaat (MM) }\end{array}$ \\
\hline
\end{tabular}

Sumber : Hasil Analisis, 2021
RQ1 mewakili keyakinan yang akan dirasakan saat melakukan pembelajaran online berupa kesulitankesulitan yang di dapat. Ini juga menunjukkan persepsi tingkat kemudahan dalam melaksanakan pembelajaran online. RQ2 juga mewakili konsekuensi yang akan dirasakan bila melakukan pembelajaran online. RQ2 menunjukkan persepsi manfaat penggunaan teknologi yang diwakili dengan melakukan pembelajaran online.

Meskipun kedua Partisipan Kunci tidak membahas prasarana sebagai kesulitan yang dialami saat pembelajaran online beberapa penelitian terdahulu menyebutkannya (Abubakar Yunusa et al., 2020; Andalecio et al., 2020; Osita Omeje et al., 2019). Partisipan Utama pada penelitian ini ternyata lebih banyak yang menyatakan bahwa kesulitan yang dialami pada saat pembelajaran online adalah masalah prasarana seperti jaringan internet, kuota internet serta listrik. Untuk gangguan jaringan internet, masalah ini merupakan masalah klasik yang memang tidak hanya dirasakan oleh dosen-dosen Universitas Dharma Andalas saja tetapi juga dirasakan oleh banyak daerah di Indonesia. $\mathrm{Di}$ beberapa negara berkembang hal yang sama juga sering dirasakan. Para dosen di Universitas Dharma Andalas termasuk dosen S1 Manajemen mulai melaksanakan pembelajaran online pada saat yang hampir bersamaan dengan perguruan tinggi lain dan lembaga-lembaga Pendidikan lain dari berbagai tingkat, maka masalah ini menjadi sangat terasa.

Masalah lain yang tidak kalah penting adalah terkait dengan metode penyajian materi yang harus diberikan oleh para dosen. Seperti yang telah disebutkan oleh Partisipan Kunci 1 kebanyakan dosen beranggapan bahwa pembelajaran online itu cara penyajian materinya sama dengan cara yang biasa 
mereka lakukan pada saat pembelajaran tatap muka, yaitu metode ceramah. Bila para dosen ini memaksakan diri memberikan ceramah secara online kepada peserta didiknya baik melalui zoom, google meet ataupun media lainnya, dengan kondisi prasarana terutama jaringan internet yang tidak terlalu mendukung baik di tempat dosen atau mahasiswanya, maka proses ceramah untuk pemberian materi itu akan mudah terganggu. Kondisi ini jelas terlihat dari hasil pengkodean tahap 2 yang menggabungkan beberapa kendala selain prasarana menjadi satu yaitu kreativitas dosen dalam proses pembelajaran. Kreativitas ini memang sangat dituntut pada saat pembelajaran online dimana dosen harus bisa meramu metode pemberian materi antara sinkron maya, asikron mandiri dan asinkron kolaboratif.

Dalam hal interaksi sosial terutama masalah pengawasan terhadap keseriusan peserta didik saat melaksanakan perkuliahan, hendaknya dosen juga bisa meramu secara kreatif, mengingat cara pengawasan seperti yang dilakukan pada pembelajaran tatap muka tidak mungkin diterapkan sepenuhnya pada pembelajaran online. Contohnya dengan lebih banyak mengajak peserta didik berdiskusi, pendapat atau jawaban yang ia berikan bisa dijadikan indikator keseriusan mereka. Kesulitan terkait rasa yang hilang dalam berinteraksi sosial baik antara dosen dengan peserta didik maupun antar peserta didik memang merupakan suatu masalah yang sulit diatasi. Sebagai makhluk sosial kebutuhan berinteraksi langsung dengan sesamanya memang tidak bisa sepenuhnya digantikan dengan interaksi secara online.

Baik kesulitan karena prasarana maupun karena kreativitas dosen dalam proses pembelajaran pada kenyataannya dirasakan oleh semua kelompok umur dosen, jenis mata kuliah yang diampu maupun jenis kelamin. Hal ini disebabkan karena pertama untuk kesulitan prasarana, hal itu terjadi umum di Indonesia dan di luar kendali yang bisa dilakukan individu per individu. Sementara masalah kedua yaitu kesulitan pada kreativitas dosen dalam proses pembelajaran kemungkinan karena selama ini para dosen belum pernah melaksanakan pembelajaran online ini sehingga menjadi suatu hal yang baru bagi para dosen. Namun setelah menjalani pembelajaran online selama 3 semester sudah semestinya para dosen mampu beradaptasi dan mengembangkan kreativitasnya. Beberapa dosen muda menunjukkan kemampuan kreativitasnya itu dengan jawaban yang cukup percaya diri pada sesi wawancara. Sementara untuk dosen senior terlihat lebih sulit beradaptasi karena mereka sudah sangat nyaman dengan metode tradisional yang biasa mereka lakukan pada saat tatap muka. Tidak ada perbedaan yang berarti dalam hal jenis kelamin. Untuk matakuliah, bagi yang mengajar hitungan, ternyata tetap ada perbedaan antara dosen muda dengan dosen senior. Oleh sebab itu bisa dikatakan kreativitas dalam meramu proses pembelajaran sepertinya juga dipengaruhi oleh faktor usia.

Terkait manfaat yang dirasa dalam pembelajaran online (RQ2) ternyata dosen muda merasakan kreativitas mereka berkembang dalam upaya penyajian materi. Hal ini sejalan dengan pendapat Partisipan Kunci. Terkait jawaban yang diperoleh pada RQ2 ini diketahui bahwa dosen senior justru lebih banyak tidak merasakan manfaat dari pembelajaran online ini, sementara dosen muda lebih merasakan manfaat dari pembelajaran online. Kemungkinan dosen senior sudah sangat nyaman dengan pembelajaran secara 
tradisional sehingga sulit untuk bisa keluar dari zona nyamannya.

Bila diperhatikan secara sikap berdasarkan jawaban yang diperoleh pada RQ1 dan RQ2 maka dapat dikatakan secara umur kedua kelompok memiliki sikap yang berbeda terhadap pembelajaran online. Dosen muda memiliki sikap yang lebih positif terhadap pembelajaran online. Dosen senior memiliki sikap yang lebih negatif terhadap pembelajaran online. Sikap ini tentunya akan mempengaruhi niat atau intensi mereka dalam metode pembelajaran yang ingin dilakukan di masa new normal.

\section{SIMPULAN}

Kesimpulan yang dapat ditarik dari penelitian ini adalah:

1. Secara garis besar kesulitan yang dihadapi oleh dosen S1 Manajemen Universitas Dharma Andalas adalah prasarana yang kurang memadai baik itu dari segi ketersediaan yang dipasok oleh Pemerintah Indonesia maupun yang diberikan oleh kampus Universitas Dharma Andalas. Prasarana di sini mencakup jaringan internet, ketersediaan kuota internet dan listrik. Selain itu juga ada kesulitan akibat masih rendahnya kreativitas dosen dalam proses pembelajaran. Kebanyakan dosen hanya memberikan materi dengan ceramah pada zoom atau google meet seperti yang mereka lakukan di pembelajaran tatap muka. Hal ini menyebabkan mereka merasa tidak dapat mengawasi kelakuan peserta didik saat pembelajaran berlangsung;

2. Tidak semua dosen S1 Manejemen Universitas Dharma Andalas yang merasakan manfaat dari pembelajaran online. Sebagian dosen S1 Manajemen Universitas Dharma Andalas dapat merasakan manfaat pembelajaran online, dan itu banyak terjadi pada dosen muda.

\section{DAFTAR PUSTAKA}

Abubakar Yunusa, A., Temitayo Sanusi, I., Alexander Dada, O., Sunday Oyelere, S., \& Joseph Agbo, F. (2020). Disruptions of Academic Activities in Nigeria: University Lecturers' Perceptions and Responses to the COVID-19. Proceedings of the 15th Latin American Conference on Learning Technologies, LACLO 2020. https://doi.org/10.1109/LACLO508 06.2020 .9381174

Ajzen, I. (1991). The Theory of Planned Behavior. Organizational Behavior and Human Decision Processes, 50, 179-211.

https://doi.org/10.1016/07495978(91)90020-T

Andalecio, A. B. P., Ferrera, E. I. V, \& Martinez, M. G. A. (2020). An Assessment of an Online Learning Program of Hospitality College in a Private University. Journal of Physics: Conference Series. https://doi.org/10.1088/17426596/1529/3/032065

Arhur, M. B., Hall, D. T., \& Lawrence, B. S. (1989). Handbook of career theory. In Cambridge University Press. Cambridge University Press. https://doi.org/10.1017/cbo9780511 625459

Awwaabiin, S. (2021). Menilik Peran Dosen dalam Implementasi Kampus Merdeka. Dunia Dosen. https://www.duniadosen.com/perandosen-dalam-implementasi-kampusmerdeka/

Brown, D. (1996). Career Choice and Development (Fourth). Jossey Boss A Wiley Company.

Burell, G., \& Morgan, G. (1979). Sociological Paradigms and Organisational Analysis (Elements 
of the Sociology of Corporate Life). Routledge.

https://doi.org/10.1007/s00113-0061227-x

Cahyono, H. (2019). Faktor-Faktor Kesulitan Belajar Siswa Min Janti. Jurnal Dimensi Pendidikan Dan Pembelajaran, $\quad 7(1), \quad 1$. https://doi.org/10.24269/dpp.v7i1.1 636

Chaeruman, U. A. (2017). PEDATI Model Desain Sistem Pembelajaran Blended. Direktorat Pembelajaran, Direktorat Jenderal Pembelajaran Dan Kemahasiswaan Kemenristek Dikti.

Chairoel, L., Fitri, M. E. Y., \& Hastini, L. Y. (2020). Persepsi Mahasiswa tentang Sistem Informasi Akademik Perguruan Tinggi. AMAR (Andalas Management Review), 4(1), 82-99. https://doi.org/10.25077/amar.4.1.8 2-99.2020

Clark, L. S. (2009). Digital media and the generation gap. Information Communication and Society, 12(3), 388-407. https://doi.org/10.1080/1369118090 2823845

Creswell, W. (2007). Qualitative Inquiry \& Research Design. Choosing among Five Approaches (Second). SAGE Publications Ltd.

Czarniawska, B. (2004). Narratives in social science research. 157.

Dewantara, J. A., \& Nurgiansah, T. H. (2020). Efektivitas Pembelajaran Daring di Masa Pandemi COVID 19 Bagi Mahasiswa Universitas PGRI Yogyakarta. Jurnal Basicedu, 5(1), 367-375.

https://doi.org/10.31004/BASICED U.V5I1.669

Dirjen Dikti Kemendikbud. (2020). Buku Panduan Merdeka Belajar Kampus Merdeka. In Direktorat Jenderal Pendidikan Tinggi Kementerian Pendidikan dan
Kebudayaan.

http://dikti.kemdikbud.go.id/wp-

content/uploads/2020/04/Buku-

Panduan-Merdeka-Belajar-Kampus-

Merdeka-2020

Doddy. (2020). Kampus Merdeka Tawarkan Pengembangan Kompetensi dan Karir bagi DosenDirektorat Jenderal Pendidikan Tinggi Kementerian Pendidikan dan Kebudayaan Republik Indonesia. https://dikti.kemdikbud.go.id/kabardikti/kabar/kampus-merdekatawarkan-pengembangankompetensi-dan-karir-bagi-dosen/

Hastini, L. Y., Fahmi, R., \& Lukito, H. (2020). Apakah Pembelajaran Menggunakan Teknologi dapat Meningkatkan Literasi Manusia pada Generasi $Z$ di Indonesia? Jurnal Manajemen Informatika. https://doi.org/https://doi.org/10.340 10/jamika.v10i1

Hendayana, Y. (2020). Peningkatan Kualifikasi dan Kompetensi Dosen Penggerak untuk Mendukung Kampus Merdeka. https://dikti.kemdikbud.go.id/kabardikti/kabar/peningkatan-kualifikasidan-kompetensi-dosen-penggerakuntuk-mendukung-kampusmerdeka/

Undang-Undang no 12 tahun 2012 tentang Pendidikan Tinggi, (2012).

Inkson, K., \& Elkin, G. (2008). Landscape with Travellers: The Context of Careers in Developed Nations. International Handbook of Career Guidance, 69-94. https://doi.org/10.1007/978-1-40206230-8_4

Jogiyanto. (2007). Sistem Informasi Keperilakuan. Yogyakarta : Andi

Kowang, T. O., Bakry, M. F., Hee, O. C., Fei, G. C., Yew, L. K., Saadon, M. S. I., \& Long, C. S. (2020). Industry 4.0 competencies among lecturers of higher learning 
institution in Malaysia. International Journal of Evaluation and Research in Education, 9(2), 303-310.

https://doi.org/10.11591/ijere.v9i2.2 0520

Latip, A. (2020). Peran Literasi Teknologi Informasi Dan Komunikasi Pada Pembelajaran Jarak Jauh Di Masa Pandemi Covid19. EDUTECH: Jurnal Inovasi Pendidikan Berbantuan Teknologi, 1(1), 11-20. https://doi.org/https://doi.org/10.378 59/eduteach.v1i2.1956

Mahyarni. (2013). Theory of Reasoned Action dan Theory of Planned Behavior (Sebuah Kajian Historis tentang Perilaku). Jurnal ElRiyasah, 4(1), 13-23. http://ejournal.uin-

suska.ac.id/index.php/elriyasah/artic le/view/17/13

Medina, L. C. (2018). Blended learning: Deficits and prospects in higher education. Australasian Journal of Educational Technology, 34(1), 4256. https://doi.org/10.14742/ajet.3100

Nehe, B. M. (2021). Analisis Konsep Implementasi Merdeka BelajarKampus Merdeka dalam Menghadapi Era Revolusi Industri 4.0 di Masa Pendemik di STKIP Setia Budhi Rangkasbitung 2021. Prosiding Seminar Nasional Pendidikan Setia Budhi, 1(1), 1319.

Ormrod, J. E. (2011). Human Learning (6th ed.). Prentice Hall.

Osita Omeje, H., Tobias Orji, C., \& Keres Okereke, G. (2019). Assessing the Extent of e-Learning Utilization by Industrial Technical Education Lecturers for Effective Teaching and Learning in Universities. Journal of Engineering and Applied Sciences, 14(11),
3790-3796.

https://doi.org/10.36478/jeasci.2019 .3790 .3796

Patton, W., \& McMahon, M. (2009). Career Development and Systems Theory: Connecting Theory and Practice. In New Horizons in Adult Education and Human Resource Development (Vol. 23, Issue 1). Sense Publishers. https://doi.org/10.1002/nha3.10330

Ristekdikti. (2017). Paparan Jenjang Jabatan Fungsional Dosen.

Sadikin, A., Hamidah, A., Studi, P., Biologi, P., Universitas, F., Kampus, J., Masak, P., Jambi, J., Bulian, M., Indah, M., Jaluko, K., Muarojambi-, K., Kode, J., \& Artikel, I. (2020). Pembelajaran Daring di Tengah Wabah Covid-19. Biodik: Jurnal Ilmiah Pendidikan Biologi, 6 nomor 02. https://doi.org/10.22437/bio.v6i2.97 59

Saunders, M., Lewis, P., \& Thornhill, A. (2016). Research Methods for Business Students. In Pearson.

Siemens, G., Gasevic, D., \& Dawson, S. (2015). Preparing for The Digital University: A Review of the History and Current State of Distance, Blended and Online Learning. Athabasca University Press, January.

https://doi.org/10.13140/RG.2.1.351 5.8483

Stephen P Robbins. (1996). Organizational Behavior. Concepts Controversies Applications. Prentice Hall. Inc, Englewoods Cliffs.

Stock, T., Obenaus, M., Kunz, S., \& Kohl, H. (2018). Industry 4.0 as enabler for a sustainable development: A qualitative assessment of its ecological and social potential. Process Safety and Environmental Protection, 118, 


\section{4-267.}

https://doi.org/10.1016/J.PSEP.2018 .06 .026

Super, D. E., \& Jordaan, P. (1973). Career Development Theory. British Journal of Guidance \& Counselling, 1(1), 3-16. https://doi.org/10.1080/0306988730 8259333

Syakdiyah, A., Nurmahmudah, F., \& Wijayanti, W. (2019). Active Learner Strategies in Era of Disruption: a Literature Review. 317(IConProCS), 165-168. https://doi.org/10.2991/iconprocs19.2019.34

Tavangarian, D., Leypold, M. E., Nölting, K., Röser, M., \& Voigt, D. (2004). Is e-Learning the solution for individual learning? Electronic Journal of e-Learnin. Electronic Journal of E-Learning, 2(2), 273 280. http://wwwra.informatik.unirostock.de

Undang-Undang Republik Indonesia No 14 tahun 2005 tentang Guru dan Dosen, 25 (2005).

Yin, R. K. (2015). Case study research : design and methods. Sage Publications.

https://id1lib.org/book/3559627/250 $74 d$ 